\title{
Comparative Analysis of the Energy Consumption of Different Wastewater Treatment Plants
}

\author{
Renan Barroso Soares ${ }^{1, ~ *, ~ M a r i n a ~ S a n t o s ~ M e m e l l i ~}{ }^{2}$, Regiane Pereira Roque ${ }^{1}$, \\ Ricardo Franci Gonçalves ${ }^{1}$ \\ ${ }^{1}$ Departamento de Engenharia Ambiental, Universidade Federal do Espírito Santo (Ufes), Vitória, Brazil \\ ${ }^{2}$ Centro Tecnológico, Universidade Federal do Espírito Santo (Ufes), Vitória, Brazil
}

\section{Email address:}

renanbarroso.offshore@hotmail.com (R. B. Soares), marina.memelli@gmail.com (M. S. Memelli), regianepr@gmail.com (R. P. Roque), rfg822@gmail.com (R. F. Gonçalves)

${ }^{*}$ Corresponding author

\section{To cite this article:}

Renan Barroso Soares, Marina Santos Memelli, Regiane Pereira Roque, Ricardo Franci Gonçalves. Comparative Analysis of the Energy Consumption of Different Wastewater Treatment Plants. International Journal of Architecture, Arts and Applications.

Vol.3, No. 6, 2017, pp. 79-86. doi: 10.11648/j.ijaaa.20170306.11

Received: October 20, 2017; Accepted: November 14, 2017; Published: December 26, 2017

\begin{abstract}
Wastewater treatment is a process of intensive use of resources, mainly energy, which accounts for 15 to $40 \%$ of the operating costs in conventional wastewater treatment systems. With the expected demographic increase and the restrictive trend in quality standards for effluent discharge, the energy consumption tends to increase further if there are no changes in the processes. The literature gathers the energy consumption of different wastewater treatment systems, in an attempt to map the processes and to help the decision making in the search for better alternatives. One of these alternatives is the recovery of energy from the sewer. The conventional treatment system requires between 0.3 and $0.6 \mathrm{kWh} / \mathrm{m}^{3}$, while the energy contained in the wastewater may be up to 10 times of the one required for the treatment. The simultaneous wastewater treatment and power generation, called the hybrid treatment system, is a worldwide trend. In Brazil, recent studies have shown, through energy balances, the energy viability of anaerobic-aerobic systems, with the production of algae. This work presents a comparative review of the energy consumption of different wastewater treatment plants, aiming at a better understanding and management of the processes. The results showed that there are few Brazilian data published, indicating that the country still demands more studies on the subject to improve its processes. In the treatment of wastewater, most studies point to the aerobic process as the largest consumer of energy, and efforts are focused on the optimization of the conventional system, but still without great achievements. Environmental goals and water supply strategies are poorly integrated with the energy handling, leading to an inefficient use, and with economic and environmental consequences.
\end{abstract}

Keywords: Wastewater Treatment Station, Energy Consumption, Bioenergy

\section{Introduction}

The water industry is a major consumer of energy, from the stage of construction of the facilities to the final demobilization of the equipment. Most of the energy is consumed at treatment plants. Typically, the energy use accounts for 5 to $30 \%$ of the operating costs of the plants in the world [1, 2]. Electricity is the predominant form of energy and it is used to power pumps, valves, compressors and other equipment [3]. In Brazil, public supply and sanitation companies spent 2.94 billion reais (about US\$ 1 billion) with energy in 2010 [4].

In addition to cost, energy use is associated with environmental problems such as greenhouse gases (GHG) emissions. A conventional treatment system, for example, has a potential to produce up to 1,400 ton of $\mathrm{CO}_{2}$ during its operation [5]. This emission of greenhouse gases also depends on the electricity generation system adopted in the country [6] and is lower in Brazil, considering the percentage of $74.6 \%$ of renewable energy in its energy matrix [7]. These impacts have been measured by methodologies such as life cycle assessment (LCA) [8], a tool standardized by ISO 
14044, which has become a reference in the environmental performance analysis of the processes [9]

Understanding and quantifying the energy use with water is crucial to the sustainable use of resources through efficient models, technology, better management, and appropriate choices for each project. Although energy and water policies are presented separately, their integration is necessary, since decisions taken on water affect the energy consumption [10]. Adequate energy-efficient treatment of water must be ensured to avoid damaging the life-sustaining foundations [11, 12].

Traditional water and wastewater systems are costly, and often inefficient and great energy users [13]. Energy consumption is considered one of the greatest anthropogenic sources of GHG and it causes some of the most relevant impacts on the global warming [10, 14]. According to [15], energy consumption contributes $57 \%$ to global warming. In the European Union, the energy and climate change strategy aims to transform the current resource-intensive economy model into a new sustainable growth model [16]. Ensuring energy and water security and reducing carbon emissions is important in the city planning [17]. Making a wastewater treatment plant (WWTP) self-sustaining in energy can improve its profitability [18] and reduce GHG emissions. However, it is still difficult to demonstrate these benefits quantitatively, and further studies are needed to overcome political, behavioral, financial and technical barriers [19]. Energy consumption in the sector appears to be under-researched and needs further exploration [20]. There is a lack of knowledge, and it is not clear how the energy consumption varies in different processes and countries [1].

\section{Literature Review}

Most of the reviews in the literature on energy consumption in WWTPs are specific to certain regions or processes, as in $[21,19,22]$. Other revisions have involved the sector as a whole, as $[6,23]$. According to [17], of the total energy consumed, $70 \%$ is used for operation and $30 \%$ for the construction. In North American WWTPs, due to the large volume of treated wastewater, $94 \%$ of the spent energy is in the plant's operating phase [23]. Data on this consumption in Brazil are scarce.

The energy consumption in the pumping of wastewater to the WWTP depends on several factors. Reference [17] estimated consumption at $0.09 \mathrm{kWh} / \mathrm{m}^{3}$ in India, or $45.3 \%$ of the total used for the WWTP operation. In the USA, the expenditure at this stage is $0.04 \mathrm{kWh} / \mathrm{m}^{3}$, in New Zealand it varies between 0.04 and $0.19 \mathrm{kWh} / \mathrm{m}^{3}$, in Canada it is around 0.02 and $0.1 \mathrm{kWh} / \mathrm{m}^{3}$ [24], in Hungary it is between 0.045 and $0.14 \mathrm{kWh} / \mathrm{m}^{3}$, and in Australia it is estimated to be between 0.1 and $0.37 \mathrm{kWh} / \mathrm{m}^{3}[21,25]$ suggested a global consumption average of 5 to $18 \%$ for pumping.

\subsection{Wastewater Treatment Energy Consumption}

The energy consumption for wastewater treatment will depend on the flow, effluent quality, types of processes adopted [18] and quality of the effluent [26]. In Germany and
Italy, about $1 \%$ of the country's energy consumption is in the WWTPs, which is a good estimate for the European countries [25], although other percentages may be described in the literature. Reference [3] cited $0.7 \%$ for Germany, $0.6 \%$ for the United States and $0.25 \%$ for China. Reference [27] reported from 0.21 to $0.49 \%$ for China. Reference [1] mentioned $0.5 \%$ for South Korea.

In general, wastewater treatment requires between 0.3 and $0.6 \mathrm{kWh} / \mathrm{m}^{3}$ [28], but when there are limitations of area or high qualities are required for the effluent, alternative technologies with higher power consumption may be adopted. [29]. Generally, the energy cost represents 15 to $40 \%$ of the total cost of operation of the WWTP, being only behind the workforce cost [30]. Regardless of its scale, each station presents opportunities to improve its energy efficiency, saving 20 to $40 \%$ and, in some cases, up to $75 \%$ [19].

Reference [25] presented a review of the literature on energy consumption in WWTPs from countries in North America, Asia and Europe. So, the preliminary treatment consumes less than $1 \%$ of the total consumed in the WWTP. In the primary treatment, very little energy is expended, while in the secondary treatment, the energy consumption varies according to the type of treatment adopted [31]. The energy expenditure in the tertiary treatment depends on the degree of necessary treatment applied to the effluents [24].

Reference [23] reported the energy consumption in WWTPs of different countries and, regardless of technology differences, the average consumption was similar, between 0.38 and $1.122 \mathrm{kWh} / \mathrm{m}^{3}$. Five WWTPs were analyzed in China, including one of the largest in the world $\left(2 \times 106 \mathrm{~m}^{3} /\right.$ day capacity), and they were compared to others in the United States, Germany and South Africa. Energy consumption was dominated by the aeration, with a lower consumption for the pumping and the sludge dewatering.

Reference [27] studied 9 WWTPs in southern China and, in a second study [32], they studied 18 WWTPs in the that country. So, it resulted that the energy expenditure in China is much lower than in more developed countries such as Japan, the Netherlands and Norway. The explanation may lie in the lower quality of the effluent in China and the modernity of its WWTPs, most of which have been built in the last 10 years with new technology, whereas the traditional plants were built 30 years ago in the developed countries. The secondary treatment consumed about $60 \%$ of the total energy, followed by the one for the pre-treatment, disinfection, dephosphorization and sludge dewatering. The technology with the lowest consumption was the anoxic-anaerobic oxidation with coupled filter.

Reference [17] analyzed the energy consumption in WWTPs of Delhi, India, where the treatment systems use the activated sludge method. Considering only the energy of the wastewater treatment, $65.5 \%$ was electric and $27.8 \%$ was associated with the materials used in the process. The energy consumption was influenced by chemicals which, when used for sludge dewatering and disinfection, accounted for $28 \%$ of the energy cost of operation.

Reference [19] evaluated 14 different WWTPs in Portugal. 
The plants with an additional biological treatment, for nutrient removal, presented a 30 to $50 \%$ higher energy intake in the aeration, pumping and solids processing when compared to the one of the conventional activated sludge system. The aeration consumed $53 \%$ of the energy and the stages of air deodorization, flow equalization and sludge dewatering also had a great contribution. The pumping energy consumption was $12 \%$ and varied according to the scale and the topography, and sometimes accounted for a large part of the consumption.

According to [30], about $20 \%$ of the energy in the WWTPs is consumed in auxiliary processes, such as pumping stations, lighting and heating, with $0.52 \mathrm{kWh} / \mathrm{m}^{3}$ being the energy used only in the treatment. The electricity consumption profile indicates that $55 \%$ of the energy is consumed in the aeration, $10 \%$ in the primary clarification and $10 \%$ in the processing of the biosolids. The author constructed a pilot WWTP, with a system of maximum removal of solids before the biological treatment, with a step of dewatering the sludge, and generating energy through anaerobic digestion or gasification. The demand for electricity in the proposed system was $85 \%$ of the one of the conventional system, and the required area was also much smaller. According to the author, only optimizing the traditional processes is not enough, since an organized effort in Switzerland only managed to save $12 \%$ of the energy consumption.

At the end of the wastewater treatment, it is still necessary to expend energy with the final disposal of the effluent, usually done in rivers and lakes. In Australia the final disposal spends $0.02 \mathrm{kWh} / \mathrm{m}^{3}$ [23]. The management of the sludge produced in the WWTPs also consumes much of the energy. In the United States, about 6.5 million tons of wastewater sludge are produced annually [28]. In Europe, the countries that produced the most sludge in 2010 were Germany, United Kingdom, Italy, France and Spain, each with 2, 1.64, 1.5, 1.3 and 1.28 million tons, respectively. For the European Union, a total amount of sludge produced is estimated at 13 million tons by 2020 [33]. In Brazil, between 150 and 220 thousand tons of sludge were produced in 2010, with a potential to quadruple this value, if collection and treatment were expanded in the country [34]. These data are on a dry basis.

On average, $30 \%$ of the WWTP costs are attributed to the sludge treatment, which needs to be stabilized prior to disposal [28]. The sludge treatment, until its final disposal, can consume between 0.074 and $0.15 \mathrm{kWh} / \mathrm{m}^{3}$ due to the different forms of management. If an aerobic treatment is applied, the consumption is compared to the one of the aeration system [25]. On the other hand, bio-drying is a process that uses the heat produced by microorganisms [35]. However, sludge has an enormous potential to generate energy, which can not only supply the energy expenditure of its management, but also transform a WWTP into a surplus energy unit [36].

With all these energy expenditures the wastewater treatment method with a hybrid system is gaining attention in recent years [37]. The system may be a combination of several processes and operational units in order to improve the quality of the wastewater effluent, with energy advantages [38]. In Brazil, the annual volume of wastewater treated is 2.6 billion cubic meters $(81 \%$ of the wastewater collected in the network), consuming 802 million $\mathrm{kWh} /$ year, or $0.24 \mathrm{kWh} / \mathrm{m}^{3}$ [39].

\subsection{Energy Generation Potential in the WWTPs}

It is estimated that the domestic wastewater has 10 times more energy, than that required for its treatment [28], consisting of chemical, thermal and hydraulic forms. Considering a chemical oxygen demand (COD) of $500 \mathrm{mg} / \mathrm{L}$, the chemical energy of the wastewater is estimated at 1.8 $\mathrm{kWh} / \mathrm{m}^{3}$ [20]. Despite the high energy content, due to thermodynamic and technological constraints, only part of this energy is recovered [30] and some challenges still must be overcome in order to recover all this energy in an economically viable way [28].

The biogas produced by the anaerobic digestion of the sludge can provide between $39 \%$ and $76 \%$ of the total energy consumed in the WWTP [40]. In the United States alone, between 628 and 4,940 million $\mathrm{kWh}$ can be saved annually by the anaerobic digestion of the wastewater sludge [23]. In Europe, in 2014, the primary energy produced from wastewater sludge biogas was $4.97 \times 1013 \mathrm{~kJ} /$ year and in Spain, the estimate is $5.94 \times 1012 \mathrm{~kJ} /$ year [40]. In a study by [17], the recovery of biogas in the WWTPs reduced the energy consumption by $33 \%$, or $0.10 \mathrm{kWh} / \mathrm{m}^{3}$. Further research also indicates that the anaerobic digestion may generate $0.1 \mathrm{kWh} / \mathrm{m}^{3}$ [3].

Reference [41] studied the economic viability for the generation of electric energy from biogas obtained in Brazilian WWTPs. A technical feasibility analysis demonstrates that it is possible to have an economic viability for the recovery of energy in a WWTP in a scale of 100 thousand inhabitants, and even smaller ones. A technical study published by the Ministry of Cities evaluated, among 5 treatment options, that the UASB anaerobic reactor system followed by an aerobic treatment, with energy production through biogas, was the most feasible, reducing the external energy demand in $99 \%$. The system presented a rate of return of $20 \%$, well above the $8.7 \%$ corresponding to the Brazilian National Bank for Economic and Social Development (BNDES) loan rate [42]. Several studies in the literature confirm the potential of the energy production through the wastewater treatment, with significant reductions of the external consumption, including the return on proven investments, such as by $[43,20,30,3]$. However, in order to translate this energy potential into reality, Brazil needs to foster the sector with policy incentives, thus giving a start to the development of the market.

\section{Discussion}

Table 1 shows a compilation of the energy consumption in the wastewater sector, with the treatment step being arranged separately in Table 2 . Table 3 shows the consumption within the treatment steps. 
Table 1. Energy consumption per process of the Sanitary Wastewater System.

\begin{tabular}{lllll}
\hline Process Step & Country & Consumption $\left(\mathbf{k W h} / \mathbf{m}^{3}\right)$ & Description & Ref. \\
\hline & California & $0.003-0.04$ & - \\
& Canada & $0.02-0.1$ & - \\
\multirow{3}{*}{ Wastewater collection } & Hungary & $0.045-0.4$ & - & 21 \\
& Australia & $0.1-0.37$ & - & \\
& USA & 0.04 & - & 17 \\
& New Zeland & $0.04-0.19$ & - & 25 \\
Sludge management & India & $0.07-0.11$ & - & \\
& World average & $0.022-0.042$ & Final disposal & 23 \\
Effluent final disposal and & World average & $0.074-0.15$ & & \\
reuse & Australia & 0.02 & Reuse & \\
& World average & $0.18-0.63$ & & \\
& Israel & 0.72 & Reuse in scattered area & \\
\hline
\end{tabular}

Table 2. Energy consumption in the wastewater treatment.

\begin{tabular}{|c|c|c|c|c|}
\hline Country & Capacity & Process & Consumption $\left(\mathrm{kWh} / \mathrm{m}^{3}\right)$ & Ref. \\
\hline World average & \multirow{17}{*}{$\begin{array}{l}2.000 \mathrm{EP} \\
100.000 \mathrm{EP}\end{array}$} & & $0.38-1.122$ & 23 \\
\hline Spain & & Conventional activated sludge & 0.5 & \multirow{4}{*}{31} \\
\hline Spain & & Activated sludge with filtration & 1.2 & \\
\hline Spain & & Immersed biological membrane reactors & 0.8 & \\
\hline Spain & & External membrane reactors & 1.0 & \\
\hline World average & & Conventional Activated Sludge & $0.3-0.65$ & 30 \\
\hline World average & & & $3.01 \mathrm{Wh} / \mathrm{kg}$ COD & \multirow{2}{*}{25} \\
\hline World average & & & $0.69 \mathrm{kWh} / \mathrm{kg}$ COD & \\
\hline South Africa & & Stabilization ponds & $0.079-0.28$ & \multirow{4}{*}{3} \\
\hline South Africa & & Thickening filter & $0.19-0.41$ & \\
\hline South Africa & & Activated sludge & $0.33-0.61$ & \\
\hline South Africa & & Aeration Ditch & $0.48-1.03$ & \\
\hline India & & & 0.19 & \multirow{2}{*}{17} \\
\hline India & & Conventional Activated Sludge & 0,26 & \\
\hline South Korea & & & 0.243 & 1 \\
\hline Germany & & & $0.95 \mathrm{kWh} / \mathrm{kg}$ COD & 25 \\
\hline Germany & & & $0.4-0.43$ & 3 \\
\hline China & \multirow{6}{*}{$2 \times 106 \mathrm{~m}^{3} /$ day } & & $0.12-0.38 \mathrm{kWh} / \mathrm{t}$ & 32 \\
\hline China & & Anoxide-anaerobic-oxide & $0.254-0.31$ & \multirow{3}{*}{3} \\
\hline China & & Anoxide-anaerobic-oxide & 0.13 & \\
\hline China & & Membrane & 0.6 & \\
\hline China & & Anoxide-anaerobic-oxide & 0.45 & \multirow{2}{*}{27} \\
\hline China & & Humic filter & 0.25 & \\
\hline China & \multirow{3}{*}{$\begin{array}{l}45 \mathrm{~m}^{3} / \text { day } \\
380 \mathrm{~m}^{3} / \text { day }\end{array}$} & Aeration trench or anoxide-oxide system or rapid infiltration & $0.4-0.5$ & \\
\hline China & & Humus biofilter & 0.15 & 3 \\
\hline Greece & & Gikas method & 0.087 & 30 \\
\hline Brazil & \multirow{13}{*}{$1,5 \times 104-106 \mathrm{~m}^{3} /$ day } & & 0.24 & 39 \\
\hline Brazil & & Conventional activated sludge system & 057 & 4 \\
\hline Canada & & & $1.65 \mathrm{kWh} / \mathrm{kg} \mathrm{COD}$ & \multirow{5}{*}{25} \\
\hline France & & & $3.33 \mathrm{kWh} / \mathrm{kg}$ COD & \\
\hline Spain & & & $0.97 \mathrm{kWh} / \mathrm{kg}$ COD & \\
\hline Italy & & & $0.85 \mathrm{kWh} / \mathrm{kg}$ COD & \\
\hline USA & & & $1.31 \mathrm{kWh} / \mathrm{kg}$ COD & \\
\hline USA & & & $0.52-0.55$ & \multirow{3}{*}{3} \\
\hline USA & & With chlorine disinfection & 0.287 & \\
\hline USA & & With UV disinfection & 1.12 & \\
\hline Fount Snain and & & Vertical flow bed & $0.45 \mathrm{~kJ}$ EP/day & \multirow{3}{*}{9} \\
\hline Egypt, Spain and & & Activated sludge & $464 \mathrm{~kJ}$ EP/day & \\
\hline France & & Activated sludge + polishing pond & $668 \mathrm{~kJ} \mathrm{EP} /$ day & \\
\hline
\end{tabular}

One can see the wide variety of information, with consumption from 0.079 to $1.122 \mathrm{kWh} / \mathrm{m}^{3}$. This is because not all WWTPs have the same levels of treatment, effluent quality standard, process technology, employee experience, and so on. The world-wide widespread technology is the activated sludge system and, when not specified by the authors, it is understood that this is the adopted process. Most energy efficiency indicators refer to the consumption of energy by the volume of treated wastewater $\left(\mathrm{kWh} / \mathrm{m}^{3}\right)$, although indicators are also found that relate consumption with the equivalent population served, or with the COD removed from the wastewater, and others. The developed countries, with more 
stringent quality standards and area limitations, can use more efficient and less built-up systems, even if they pay the price of higher energy consumption. Otherwise, developing countries may resort to less efficient techniques with greater area demand to save energy. At different levels of treatment, different energy consumption is observed; however, there is a typical behavior: low consumption in preliminary and primary treatments and higher consumption in secondary and tertiary treatments.

In Brazil, due to the relatively warm climate all year round, the anaerobic treatments are possible, which may explain the lower energy consumption compared to the world average. On the contrary, the system is a strong candidate to generate energy through the biogas produced. In the country, the PROBIOGÁS project, a cooperation between the Brazilian Government and the German Government, is under way with the objective of increasing the use of biogas in Brazil [44]. Today, most of the biogas produced in the WWTPs is simply burned, without any energy use. Energy recovery from the sludge produced in the treatment is also important, especially when noticing the large energy consumption in the sludge management. For the pumping of wastewater, the consumption tends to be lower in developing countries, where the exhaustion in open channels is common, and cheaper than the underground network, but with damages to the aesthetics of the city plus health risks.

Table 3. Energy consumption per level of wastewater treatment.

\begin{tabular}{|c|c|c|c|c|}
\hline Local & Treatment & Process & Consumption $\left(\mathrm{kWh} / \mathrm{m}^{3}\right)$ & Ref. \\
\hline World average & Preliminary & Railing & $2.9 \times 10-5-0.013$ & \multirow{2}{*}{25} \\
\hline World average & Preliminary & Decantation tanks with mechanical scrapers & $4.3 \times 10-5-7.1 \times 10-5$ & \\
\hline China & Preliminary & & $0.002-0.076 \mathrm{kWh} / \mathrm{t}$ & 32 \\
\hline Ireland & Preliminary & Aerated filter & $50.01 \mathrm{kWh} /$ day & 26 \\
\hline Australia & Primary & & $0.01-0.37$ & 23 \\
\hline World average & Primary & Decanting & $4.3 \times 10-5-7.1 \times 10-5$ & \multirow{5}{*}{25} \\
\hline World average & Secondary & Sludge separation & $0.0084-0.012$ & \\
\hline World average & Secondary & Sludge circulation & $0.047-0.01$ & \\
\hline World average & Secondary & Blending & $0.053-0.12$ & \\
\hline World average & Secondary & Aeration & $0.18-0.8$ & \\
\hline China & Secondary & Biochemical & $0.008-0,229 \mathrm{kWh} / \mathrm{t}$ & 32 \\
\hline Japan & Secondary & & 0.34 & \multirow{5}{*}{23} \\
\hline Sweden & Secondary & & 0.42 & \\
\hline China & Secondary & & 0.29 & \\
\hline USA & Secondary & & 0.2 & \\
\hline Australia & Secondary & & 0.305 & \\
\hline Ireland & Secondary & Activated Sludges & $1,366.9 \mathrm{kWh} /$ day & \multirow{3}{*}{26} \\
\hline Ireland & Secondary & Activated Sludges & $450 \mathrm{kWh} /$ day & \\
\hline World average & Terciary & & $0.40-0.50$ & \\
\hline China & Terciary & & 0.25 & \multirow{4}{*}{23} \\
\hline Germany & Terciary & & 0.67 & \\
\hline Spain & Terciary & Membrane & 0.8 & \\
\hline Saudi Arabia & Terciary & Membrane & 1.6 & \\
\hline China & Terciary & & $0.001-0.009 \mathrm{kWh} / \mathrm{t}$ & 32 \\
\hline World average & Terciary & UV & $0.045-0.11$ & \multirow{4}{*}{25} \\
\hline World average & Terciary & Chlorine Dosers & $0.009-0.015$ & \\
\hline World average & Terciary & Filtration & $0.0074-0.0027$ & \\
\hline World average & Sludge & Centrifugation & 0.018 .0 .027 & \\
\hline China & Sludge & & $0.001-0.0043 \mathrm{kWh} / \mathrm{t}$ & 32 \\
\hline
\end{tabular}

Almost all the authors studied report the benefits of the scaling to reduce the energy consumption in the WWTPs, although small plants can also have good efficiency and low consumption. In addition to energy savings, larger scales still enable the recovery of energy in plants, through more expensive and complex equipment such as gasifier and fuel cells. Among the huge potential for the recovery of the energy contained in the wastewater, which contains energy in the form of heat, the heat pumps are still expensive and the system is more used to harness the thermal energy from industrial wastewater. When the wastewater temperature is significantly different from the ambient temperature, or from the temperature of other streams in the treatment plant, there is a potential for heat transfer. A heat pump is a device that uses a refrigerant fluid to recover heat from a relatively low temperature source, such as the sanitary sewer, and to transfer it to a higher temperature medium through an external source of energy. Briefly, the refrigerant fluid, at low temperature and pressure, is vaporized through the use of an external source of heat, within a heat exchanger system. Then, the refrigerant is compressed, and reaches high pressures and temperatures. This fluid is then fed into another heat exchanger, supplying its energy to another system, which can be used for various purposes. The remaining coolant pressure is released into an expansion valve, and the cycle is complete [18]. With increasing restrictions on the disposal of sludge in landfills 
(already banned in some European countries) and in agriculture, the recovery of the sludge chemical energy through anaerobic digestion and gasification has been increasingly promising. Several WWTPs are already operating on a surplus energy basis and the data prove that making a self-sustaining WWTP in energy is economically viable. Despite the high investments, there is a return on the business. In addition to direct energy savings, reducing the electricity consumption avoids peak demand, which usually has a surcharge on energy prices.

\section{Conclusion}

This work presents a review of the literature on the energy consumption in the wastewater sector, aiming at a better understanding to improve the management of WWTPs, including its energy recovery. There are few Brazilian data published, indicating that the country still demands more studies on the subject to improve its processes. Applying technologies defined by other countries may not be the best option, as the climate conditions, as well as the availability of resources, differ significantly among regions. One must always be in search of a national technology, allied to the international development. In the treatment of wastewater, most studies point to the aerobic process as the largest consumer of energy, and efforts are focused on the optimization of the conventional system, but still without great achievements. In Brazil, the scenario is completely different, as the potential for energy production in anaerobic systems is enormous, even more if we consider the sanitation deficit and the expected expansion for the sector. Resources management and policies for the industry need to be improved. Environmental goals and water supply strategies are poorly integrated with the energy handling, leading to an inefficient use, and with economic and environmental consequences. Policies to stimulate the rational use of water and its reuse, as the Chinese government has implemented and some Brazilian cities that face water shortages are doing now, for example, help to reduce the energy consumption, since much of the water used becomes wastewater. Incentives and investments in the sector, to recover the energy potential of the wastewater, besides fostering the energy self-sufficiency of the WWTPs, which collaborate for the production of a clean and renewable energy in the country, will lead to economic gains; these gains could boost the growth of the basic sanitation in the country and help to unlock the national health system.

\section{Acknowledgements}

The researches work of our group, Núcleo Água/UFES are supported by the Fundação de Amparo à Pesquisa e Inovação do Espírito Santo (FAPES, project PPE-Agro 06-2015) and Financiadora de Estudos e Projetos (FINEP, project RENTED 06/2010), which is gratefully acknowledged.

\section{References}

[1] KANG, J.; CHAE, K. J. Estimating the energy independence of a municipal wastewater treatment plant incorporating green energy resources. Energy Conversion and Management, v. 75, p. $664-672,2013$

[2] TOJA, Yago L., ROWE, Ian V., AMORES, María J., RIFÉ, Montserrat T., NAVARRO Desirée M., MOREIRA, María T., FEIJOO, Gumersindo. Benchmarking wastewater treatment plants under an eco-efficiency perspective. Science of the Total Environment, v. 566-567 p. 468-479, 2016.

[3] WANG, H.; YANG, Y.; KELLER, A. A.; LI, X.; FENG, S.; DONG, Y.; LI, F. Comparative analysis of energy intensity and carbon emissions in wastewater treatment in USA, Germany, China and South Africa. Applied Energy, in press, 2016.

[4] VIEIRA, A. S.; GHISI, E. Water-energy nexus in low-income houses in Brazil: the influence of integrated on-site water and wastewater management strategies on the energy consumption of water and sewerage services. Journal of Cleaner Production, v. 133, p. 145-162, 2016.

[5] MUGA, H. E., MIHELCIC, J. R. Sustainability of wastewater treatment technologies. Journal of Environmental Management, v. 88 , p. $437-447,2008$.

[6] LEMOS, D., DiAS, A. C., GABARRELL, X., ARROJA, L. Environmental assessment of an urban water system. Journal of Cleaner Production, v. 54, p. 157- 165, 2013.

[7] BRASIL. Ministério de Minas e Energia. Balanço Energético Nacional, ano base 2014, 2015.

[8] BALKEMA, Annelies J., PREISIG, Heinz A., OTTERPOHL, Ralf, LAMBERT, Fred J. D. Indicators for the sustainability assessment of wastewater treatment systems. Urban Water, v. 4, p. 153-161, 2002.

[9] RISCH, E.; GUTIERreZ, O.; ROUX, P.; BOUTIN, C.; COROMINAS, L. Life cycle assessment of urban wastewater systems: Quantifying the relative contribution of sewer systems. Water Research, v. 77, p. 35-48, 2015.

[10] VILANOVA, Mateus R. N., BALESTIERI, José A. P. Exploring the water-energy nexus in Brazil: The electricity use for water supply. Energy, v. 85, p. 415-432, 2015.

[11] BUONOCORE, E.; MELLINO, S.; ANGELIS, G.; LIU, G.; ULGIATI, S. Life cycle assessment indicators of urban wastewater and wastewater sludge treatment. Ecological Indicator, in press, 2016.

[12] SPERLING, M. V. Wastewater Characteristics, Treatment and Disposal. Editora IWA, Biological Wastewater Treatment Series, volume 1, 2007.

[13] MAhgoub, M. E. M.; STEEN, N. P.; ZEID, K. A.; VAIRAVAMOORTHY, K. Towards sustainability in urban water: a life cycle analysis of the urban water system of Alexandria City, Egypt. Journal of Cleaner Production, v. 18, p. 1100-1106, 2010.

[14] VILANOVA, Mateus R. N., BALESTIERI, José A. P. Modeling of hydraulic and energy efficiency indicators for water supply systems. Renewable and Sustainable Energy Reviews, v. 48, p. 540-557, 2015. 
[15] Fundação Nacional de Saúde (FUNASA). Manual de Saneamento. Editora Assessoria de Comunicação e Educação em Saúde, $4^{\mathrm{a}}$ edição revisada, 2006.

[16] SANTOS, A. C.; PUCH, G. Z.; DIEZ, D. B.; DIÉGUEZ, C. G. Thermodynamic and exergoeconomic analysis of energy recovery system of biogas from a wastewater treatment plant and use in a Stirling engine. Renewable Energy, v. 88, p. 171-184, 2016.

[17] SINGH, P.; KANSAL, A. Energy and GHG accounting for wastewater infrastructure. Resources, Conservation and Recycling, in press, 2016.

[18] METCALF \& EDDY. Tratamento de efluentes e recuperação de recursos. Editora AMGH, 5a Edição, 2013. Tradução Ivanildo Hespanhol e Jose Calos Mierzwa, 2016.

[19] CATARINO, J.; HENRIQUES, J. Sustainable value e an energy efficiency indicator in wastewater treatment plants. Journal of Cleaner Production, in press, 2016.

[20] VARBANOV, P.; ENDERLE, P.; NOWAK, O. Ways to optimize the energy balance of municipal wastewater systems: lessons learned from Austrian applications. Journal of Cleaner Production, v. 88, p. 125-131, 2015.

[21] BODÍK, I., KUBASKÁ, M. Energy and sustainability of operation of a wastewater treatment plant. Environment Protection Engineering, v. 39, p. 15-24, 2013.

[22] PANEPINTO, D., FIORE, S., ZAPPONE, M., GENON, G., MEUCCI, L. Evaluation of the energy efficiency of a large wastewater treatment plant in Italy. Applied Energy, v. 161, p. 404-411, 2016

[23] WAKEEL, M.; CHEN, B.; HAYAT, T.; ALSAEDI, A.; AHMAD, B. Energy consumption for water use cycles in different countries: A review. Applied Energy, v. 178, p. $868-885,2016$

[24] MATOS, C., PEREIRA, S., AMORIM, E. V., BENTES, I., BRIGA-SÁ, A. Wastewater and greywater reuse on irrigation in centralized and decentralized systems- An integrated approach on water quality, energy consumption and $\mathrm{CO} 2$ emissions. Science of the Total Environment, v. 493, p. 463-471, 2014.

[25] LONGO, S.; D'ANTONI, B. M.; BONGARDS, M.; CHAPARRO, A.; CRONRATH, A.; FATONE, F.; LEMA, J. M.; IGLESIAS, M. M.; SOARES, A.; HOSPIDO, A. Monitoring and diagnosis of energy consumption in wastewater treatment plants. A state of the art and proposals for improvement. Applied Energy, v. 179, p. 1251-1268, 2016.

[26] FITZSIMONS, L., HORRIGAN, M., MCNAMARA, G., DOHERTY, E., PHELAN, T., CORCORAN, B., DELAURE, Y., CLIFFORD, Eoghan. Assessing the thermodynamic performance of Irish municipal wastewater treatment plants using exergy analysis: a potential benchmarking approach. Journal of Cleaner Production. v. 131, p. 387-398, 2016.

[27] LI, F.; CHIRAMBA, T.; XU, J.; KELLER, A.; WANG, H.; DONG, Y.; GU, Y. Quantification of the water, energy and carbon footprints of wastewater treatment plants in China considering a water-energy nexus perspective. Ecological Indicators, v. 60, p. 402-409, 2016(a).

[28] SHEN, Y.; LINVILLE, J. L.; DEMIRTAS, M. U.; MINTZ, M M.; SNYDER, S. W. An overview of biogas production and utilization at full-scale wastewater treatment plants (WWTPs) in the United States: Challenges and opportunities towards energy-neutral WWTPs. Renewable and Sustainable Energy
Reviews, v. 50, p. 346-362, 2015.

[29] GARRIDO, R. S., SENANTE, M. M., SANCHO, F. H. Comparing the efficiency of wastewater treatment technologies through a DEA metafrontier model. Chemical Engineering Journal. v. 173, p. 766-772, 2011.

[30] GIKAS, P. Towards energy positive wastewater treatment plants. Journal of Environmental Management, in press, 2016.

[31] ORTIZ, M., RALUY, R. G., SERRA, L. Life cycle assessment of water treatment technologies: wastewater and water-reuse in a small town. Desalination, v. 204, p. 121-131, 2007.

[32] LI, W.; LI, L.; QIU, G. Energy consumption and economic cost of typical wastewater treatment systems in Shenzhen, China. Journal of Cleaner Production, in press, 2016(b).

[33] ZABAniOTOU, A. A.; SAMOLADA, M. C. Comparative assessment of municipal wastewater sludge incineration, gasification and pyrolysis for a sustainable sludge-to-energy management in Greece. Waste Management, v. 34, p. 411-420, 2014.

[34] PEDROZA, M. M.; VIEIRA, G. E. G.; SOUSA, J. F.; PICKLER, A. C.; LEAL, E. R. M.; MILHOMEN, C. C. Produção e tratamento de lodo de esgoto - uma revisão. Revista Liberato, Novo Hamburgo, v. 11, p. 89-118, 2010.

[35] WINKLER, M. K., BENNENBROEK, M. H., HORSTINK, F. H., VAN LOOSDRECHT, M. C. M., van de Pol, G.-J. The biodrying concept: an innovative technology creating energy. Bioresource Technology, v. 147, p. 124-129, 2013.

[36] PRADEL, Marilys, AISSANI, Lynda, VILLOT, Jonathan, BAUDEZ, Jean-Christophe, LAFOREST, Valérie. From waste to added value product: towards a paradigm shift in life cycle assessment applied to wastewater sludge e a review. Journal of Cleaner Production. v. 131, p. 60-75, 2016.

[37] VYMAZAL, J. Horizontal sub-surface flow and hybrid constructed wetlands systems for wastewater treatment. Ecology Engineer. v. 25(5), p. 478-90, 2005.

[38] TEE, Pei F., ABDULlAH, Mohammad O., TAN, Ivy A. W., RASHID, Nur K. A., AMIN, Mohamed A. M., HIPOLITO, Cirilo N., BUJANG, Kopli. Review on hybrid energy systems for wastewater treatment and bio-energy production. Renewable and Sustainable Energy Reviews, v. 54, p. 235-246, 2016.

[39] BRASIL. Ministério das Cidades. Sistema Nacional de Informações sobre Saneamento (SNIS), Diagnóstico dos Serviços de Água e Esgotos - 2014, 2016.

[40] SILVESTRE, G., FERNÁNDEZ, B., BONMATÍ, A. Significance of anaerobic digestion as a source of clean energy in wastewater treatment plants. Energy Conversion and Management, v. 101, p. 255-262, 2015.

[41] SANTOS, I. F. S.; BARROS, R. M.; FILHO, G. L. T. Electricity generation from biogas of anaerobic wastewater treatment plants in Brazil: an assessment of feasibility and potential. Journal of Cleaner Production, v. 126, p. 504-514, 2016.

[42] PROBIOGAS - Projeto Brasil-Alemanha de Fomento ao Aproveitamento Energético de Biogás no Brasil. Viabilidade técnico-econômica de produção de energia elétrica em ETEs a partir do biogás, Brasília, 2016. Disponível em: $<$ http://www.cidades.gov.br/saneamento-cidades/probiogas/pu blicacoes/publicacoes-do-probiogas $>$. Acessado em $19 / 11 / 2016$ 
[43] AZEREDO, L. Z. Potencial energético de uma estação de tratamento de esgoto sanitário dotada de um reator anaeróbio do tipo UASB, uma lagoa de alta taxa e um processo de separação e reciclagem da biomassa algácea. Vitória, 81p, 2016. Dissertação (Mestrado) - Universidade Federal do Espírito Santo.
[44] BRASIL. Ministério das Cidades. Guia Prático do Biogás: Geração e Utilização. Editora Fachagentur Nachwachsende Rohstoffe e. V. (FNR), $5^{\text {a }}$ edição revisada, 2010, traduzido por Marcos de Miranda Zattar. 